\title{
GEMIN2 Gene
}

National Cancer Institute

\section{Source}

National Cancer Institute. GEMIN2 Gene. NCI Thesaurus. Code C114433.

This gene is involved in spliceosome formation. 